\title{
The Effect of Using Text Structure Strategy (TSS) on Enhancing EFL Preparatory Stage Pupils' Reading Comprehension Skills and Their Attitude
}

\author{
Sara Mahmoud Tolba Mohamed
}

\begin{abstract}
The present study aimed at investigating the effect of using Text Structure Strategy (TSS) on enhancing 2nd EFL preparatory stage pupils' reading comprehension skills and their attitude. The targeted reading comprehension sub- skills were (understanding, text attack skills, searching, inference ,prediction ,problem solving). The participants of the study were eighty- 2nd year preparatory pupils drawn from" Kolongnile School for Basic Education" in Mansoura city. They were divided into two groups: an experimental group who received the TSS treatment and a control group who received the traditional method of teaching. Each group consisted of forty $(\mathrm{N}=40)$ pupils. The experimental treatment was conducted during the second semester in the academic year 2016/2017. The study adopted the quasi-experimental design. Three instruments were used: Reading Comprehension Skills questionnaire to determine the most suitable reading comprehension skills for second year preparatory pupils, Reading Comprehension Skills test , and an attitude scale to identify the pupils' attitudes towards reading. Results indicated that Text Structure Strategy( TSS) helped participants improve their EFL Reading Comprehension Skills and enhance their attitude towards reading.
\end{abstract}

Key words: Text Structure Strategy (TSS), EFL Reading Comprehension Skills (RCS), and Attitude.

\section{Introduction:}

The process of reading comprehension requires a number of cognitive factors that can be assessed and observed indirectly such as background knowledge, vocabulary fluency, active reading skills and critical thinking that must work together (Pearson \& Hamm, 2005). A text is a linguistic unit for discussing a topic about which different people have different ways of expanding their own knowledge (Zhang, 2008). The text by itself does not transfer meaning, unless it is a guide for readers to organize the intended meaning of their own already existing knowledge.

One of the most important aspects of any written text is its structure (Meyer \& Poon, 2001). Text structure has many aspects that can help the reader understand what type of text is being used. There are two kinds of texts: informational or expository text. The most commonly used is text structure which has five components :cause and effect, compare and contrast, and description and classification (Pacific Resources for Education and Learning, 2008). Many pupils enjoy reading narrative 
text which has a storyline or plot, so expository text is often considered uninteresting for reading comprehension.

Hall, Sabey, and McClellan (2005) suggest that teaching text structure is an effective strategy for promoting expository text comprehension at the intermediate level. Teaching particular text structures can help readers monitor their comprehension. Attempting to identify the text structure early in reading a new text encourages pupils to question how subsequent sections of the text fit into the identified text structure.

The current study attempts to investigate the effect of using Text Structure Strategy(TSS) on enhancing EFL reading comprehension for second year preparatory pupils and develop their attitude towards reading.

\section{Review of Literature}

Due to the importance of reading comprehension skills, a lot of researches and studies have been conducted on this topic.

Rabani, Akhondi, and Azizmalayeri (2015) conducted a study to enhance reading comprehension through text structure strategies of expository passages. Reading instructions were presented in two methods; One through the use of information processing strategies which were designed based on a special focus on text structures; the other through the use of the traditional techniques of reading comprehension instructions. The results revealed that the use of information processing strategies through text structures was an effective strategy to help EFL learners to enhance their reading comprehension.

Babaie and Fard (2014) study aimed at investigating the effect of collocation awareness and text structure awareness on reading comprehension among Iranian preuniversity students(60) female students were selected from among 92 pre-university students. After administering the Nelson Proficiency Test, 30 students whose score range fell one standard deviation above the mean were selected as intermediatelevel students and 30 students whose score range fell one standard deviation below the mean as low-level students and divided into two groups; each group consisted of 15 students at intermediate-level and low-level of proficiency respectively (including a control group and an experimental group).

Dorkchandra (2012) conducted a study to enhance English reading comprehension through a text structure reading strategy CALL program. Pre and post tests used in this study to test candidates' understanding of the structure of the text and specific information. A questionnaire was also developed to investigate the participants' opinions towards the CALL program and its usefulness. The results showed that the students who learned with the program had significantly higher posttest scores than the students who did not learn with it and that they had 
very positive opinions towards the CALL program and its usefulness.

Mehrpour, Sadighi and Bagheri (2012)study of teaching reading comprehension strategies to Iranian EFL Pre-university students aimed at raising learner readers' awareness of reading strategies and enhance their reading comprehension ability. To collect the necessary data, the researcher used a reading comprehension test and two questionnaires. The findings of the study pointed to the problematic nature of reading strategy instruction. It was found that reading strategy instruction was not able to enhance the students' reading performance at the end of the study.

Newman (2007) investigated the effect of explicit instruction of expository text structure on reading comprehension. The subjects were third grade EFL students and they were divided into two groups of experimental and a control group. The experimental group received training on text structure with the use of graphic organizer. The students in the control classroom received regular Guided Reading instruction. The trainer used different reading strategies such as modeling, thinking aloud, and graphic organizers during the treatment of experimental group. After the post-test subjects of control and the experimental group showed a significant difference in their ability to comprehend expository text.

Manning (2003) conducted a
study to improve reading
comprehension through visual tools.

Student performance was measured using reading scores before and after the introduction of Thinking Maps, i.e., a set of visual tools which are centered on the development of eight thinking processes. By integrating this common visual language throughout the school's curriculum, it was projected that more effective and efficient learning would be achieved. Assessment results indicated that reading comprehension was increased; it was also observed by classroom teachers that levels of performance rose overall in the following areas: concept attainment, reflective thinking, recall, retention, writing (quantity and quality), creativity, motivation, and cooperative learning skills.

Piyanukool (2001) investigated the effectiveness of teaching reading through discussion of text structures on students' reading comprehension. In the training procedure, both narrative and expository text structures were used. The control group was asked to answer the questions at the end of stories. After the post-test, a t-test was used. The results did not reveal any differences between two groups' performance but it was found that the participants liked reading through discussion of text structures more than reading by themselves.

Studies reviewed above show that text structure was approached through various types of strategies, all of which proved to enhance the reading comprehension skills of the target samples. However, none of 
these studies used Text Structure Strategy (TSS). Therefore, this study focuses on the effect of using Text Structure Strategy(TSS)that might enhance 2nd year preparatory pupils 'EFL reading comprehension skills and develop their attitude towards reading.

\section{The pilot study:}

The researcher conducted a pilot study to measure 2nd preparartory stage pupils' current level of EFL Reading Comprehension skills and attitude. A selected sample was taken from "Kolongnile School for Basic Education" in Mansoura city to check the pupils' Reading Comprehension skills on the first term exam, 2015. The sample included forty $(n=40)$ participants. The following table shows the mean score and the percentage of Reading Comprehension section on the test. (see appendix 1).

Table (1) : Pupils' mean score in the pilot study exam and SD on the Reading Comprehension Test $(N=40)$

\begin{tabular}{|c|c|c|c|}
\hline Reading Comprehension sub-skills & N & $\begin{array}{c}\text { Mean } \\
\text { Score }\end{array}$ & Std. Deviation \\
\hline Understanding & 40 & 0.35 & 0.27 \\
\hline Text Attack Skills & 40 & 0.725 & 0.31 \\
\hline Searching & 40 & 0.881 & 0.294 \\
\hline Inference & 40 & 1.292 & 0.445 \\
\hline Prediction & 40 & 0.45 & 0.511 \\
\hline Problem Solving Solving & 40 & 1.25 & 1.12 \\
\hline Total & 40 & 4.948 & 2.95 \\
\hline
\end{tabular}

Table (1) shows the total score

of Reading Comprehension test was (4.948) that is considered an indication of the pupils' low level in Reading Comprehension Skills (Understanding,Text Attack Skills, Searcing, Inference, Prediction, and Problem Solving). The highest mean score was (1.292) in Inference subskill while the lowest mean was (0.35)in the Understanding . This level may be due to a number of variables that include the lack of training in using appropriate Reading Comprehension Skills.

\section{Statement of the problem}

Based on the review of literature, related studies, and results of the pilot study, it is evident that pupils of EFL 2nd year preparatory stage need more help to enhance their reading comprehension skills. Therefore, the current study suggests utilizing Text Structure Strategy(TSS)that might enhance the participants' reading comprehension skills and develop their attitude towards reading . 


\section{Questions of the study:}

1- What are the most important reading comprehension skills necessary for EFL 2nd preparatory pupils?

2- What are the components of Text Structure Strategy (TSS) to enhance EFL preparatory pupils in reading comprehension skills?

3- What is the effect of Text Structure Strategy(TSS) on enhancing EFL pupils' reading comprehension skills?

4- What is the effect of Text Structure Strategy(TSS) on enhancing EFL pupils' attitude towards reading?

\section{Hypotheses}

1 - There is a statistically significant difference at 0.05 level between the mean score of the experimental group and the control group on the post administration of reading comprehension test in favor of the experimental group.

2- There is a statistically significant difference at 0.05 level between the mean score of the experimental group in reading comprehension test in favor of the pre- post administration.

3- There is a statistically significant difference at 0.05 level between the mean score of the experimental group and the control group on the post administration of attitude scale in favor of the experimental group.

4- There is a statistically significant difference in 0.05 level mean score of the experimental group in the attitude scale in favor of the pre-post administration.

\section{Purpose:}

This study aimed at:

1- Investigating the effect of Text Structure Strategy (TSS) on enhancing reading comprehension skills of 2 nd year preparatory stage pupils.

2- Improving the participants' attitude towards reading comprehension skills.

\section{Delimitations:}

This study delimited to:

1. 1-Second year preparatory pupils of Colongil School in Mansoura city.

2. Some Text Structure Strategies (TSS) as (cause and effect, compare and contrast, problem and solution, question and answer, description and classification).

3. The second year EFL preparatory stage textbook (Hello5! English for Preparatory Schools).

4. Reading comprehension skills needed for EFL Second year preparatory stage pupils which are (skimming, scanning, predicting ,problem-solving, and compare and contrast ) for comprehending reading passages.

\section{Research Design}

This study is a quasiexperimental study that aimed to investigate the effectiveness of TSS in improving reading comprehension and attitude for EFL second year preparatory school pupils. 


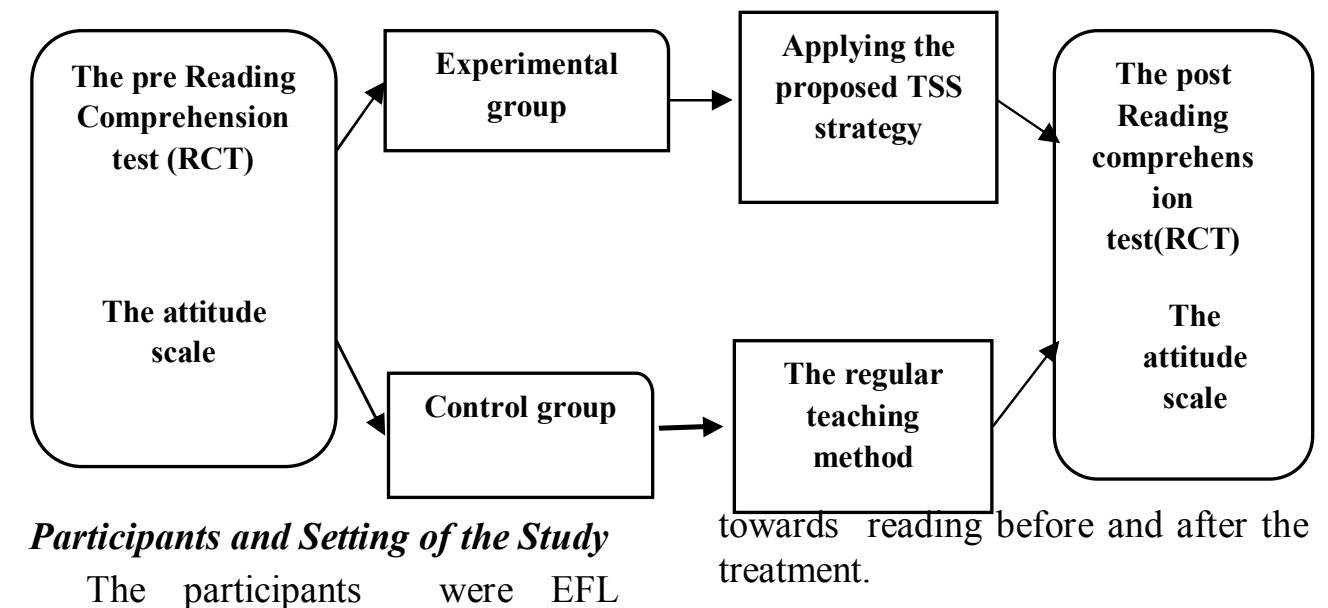

The participants were EFL second year preparatory stage pupils from Colongile School in Mansoura city. Those participants were randomly selected in school. The study was conducted in two classes where the experimental group was trained according to the proposed training via using the TSS and the control group was trained according to the regular teaching of reading comprehension skills.

\section{Instruments}

For the purpose of this study, the following instruments were designed and used:

1-A pre- post reading Comprehension Test (RCT) to measure the reading comprehension skills of 2 nd year EFL preparatory stage pupils before and after the experiment.

2-An attitude scale for assessing 2 nd year EFL preparatory pupils' attitude

\section{Results and Discussions}

Results were statistically analyzed in terms of the hypotheses. They were discussed in the light of the theoretical background and related studies. Results were reported as follows:

\section{1-Testing the first hypothesis:}

The first hypothesis stated that "There is a statistically significant difference at 0.05 level between the mean score of the experimental group and the control group on the post administration of reading comprehension test in favor of the experimental group".

Table (2) reports the results of the t-test in comparing the pupils' mean score in Reading Comprehension subskills post test and the overall performance for the experimental and control group. 
Table (2): A comparison between the mean score of the Experimental and control groups on the post administration of the Reading Comprehension test

\begin{tabular}{|c|c|c|c|c|c|c|}
\hline \multirow{2}{*}{ Skills } & \multirow{2}{*}{ Groups } & \multirow{2}{*}{$\mathbf{N}$} & \multirow{2}{*}{ Mean } & \multirow{2}{*}{$\begin{array}{c}\text { Std. } \\
\text { Deviation }\end{array}$} & \multicolumn{2}{|c|}{ Paired T-test } \\
\hline & & & & & $\mathbf{T}$ & Sig \\
\hline \multirow[t]{2}{*}{ Understanding } & \multirow{2}{*}{ Exp Cont } & 40 & 5.1750 & 1.21 & \multirow{2}{*}{7.165} & \multirow{2}{*}{0.01} \\
\hline & & 40 & 3.1000 & 1.19588 & & \\
\hline \multirow{2}{*}{ Text Attack Skills } & \multirow{2}{*}{ Exp Cont } & 40 & 4.2250 & 1.02250 & \multirow{2}{*}{7.227} & \multirow{2}{*}{0.01} \\
\hline & & 40 & 2.6750 & 0.89120 & & \\
\hline \multirow[t]{2}{*}{ Searching } & \multirow{2}{*}{ Exp Cont } & 40 & 5.3750 & 1.23387 & \multirow{2}{*}{8.553} & \multirow{2}{*}{0.01} \\
\hline & & 40 & 3.0500 & 1.19722 & & \\
\hline \multirow[t]{2}{*}{ Inference } & \multirow{2}{*}{ Exp Cont } & 40 & 4.8250 & 1.29867 & \multirow{2}{*}{7.863} & \multirow{2}{*}{0.01} \\
\hline & & 40 & 2.8000 & 0.99228 & & \\
\hline \multirow[t]{2}{*}{ Prediction } & \multirow{2}{*}{ Exp Cont } & 40 & 3.9000 & 0.98189 & \multirow{2}{*}{9.109} & \multirow{2}{*}{0.01} \\
\hline & & 40 & 1.9000 & 0.98189 & & \\
\hline \multirow{2}{*}{ Problem Solving } & \multirow{2}{*}{ Exp Cont } & 40 & 3.0500 & 0.71432 & \multirow{2}{*}{11.049} & \multirow{2}{*}{0.01} \\
\hline & & 40 & 1.2500 & 0.74248 & & \\
\hline
\end{tabular}

Results in table (2) indicate that the mean score of the pupils in each Reading Comprehension sub-skill in the experimental post-test was higher than that of pupils' in the control group .Moreover, the table shows that the pupils mean score in the overall post- Reading Comprehension test in the experimental group was (3.026) compared to the control group overall score in the post-test (26.55) .

The paired t-test results indicate that the difference between the mean score of the pupils in the post-Reading Comprehension test was statistically significant at the 0.5 level in favor of the post administration of the TSS for the Experimental group.

\section{2- Testing the second hypothesis:}

The second hypothesis stated that " There is a statistically significant difference at 0.05 level between the mean score of the experimental group in reading comprehension test in favor of the pre- post administration".

To test the second hypothesis ,the t-test for paired samples was used to compare the difference between the mean score of the experimental group pupils in Reading Comprehension test before and after administering the study intervention for using (TSS) Text Structure Strategy to determine the effect of the study intervention on their Reading Comprehension subskills. Table (3) presents the results. 
Table (3): Comparison between the experimental group pre and post administration of Reading Comprehension test

\begin{tabular}{|c|c|c|c|c|c|c|}
\hline \multirow{2}{*}{ Skills } & \multirow{2}{*}{ Groups } & \multirow{2}{*}{$\mathbf{N}$} & \multirow{2}{*}{ Mean } & \multirow{2}{*}{$\begin{array}{c}\text { Std. } \\
\text { Deviation }\end{array}$} & \multicolumn{2}{|c|}{ Paired T-test } \\
\hline & & & & & $\mathbf{T}$ & Sig \\
\hline \multirow[t]{2}{*}{ Understanding } & Pre & 40 & 3.1000 & 1.21 & \multirow{2}{*}{7.532} & \multirow{2}{*}{0.01} \\
\hline & Post & & 5.1750 & 1.19588 & & \\
\hline \multirow[t]{2}{*}{ Text Attack Skills } & Pre & 10 & 2.6750 & 1.02250 & \multirow{2}{*}{6.849} & \multirow{2}{*}{0.01} \\
\hline & Post & 40 & 4.2250 & 0.89120 & & \\
\hline \multirow[t]{2}{*}{ Searching } & Pre & 40 & 3.2250 & 1.16548 & \multirow{2}{*}{7.717} & \multirow{2}{*}{0.01} \\
\hline & Post & 40 & 5.3750 & 1.23387 & & \\
\hline \multirow[t]{2}{*}{ Inference } & Pre & & 2.8250 & 0.98417 & \multirow{2}{*}{7.464} & \multirow{2}{*}{0.01} \\
\hline & Post & 40 & 4.8250 & 1.29867 & & \\
\hline \multirow[t]{2}{*}{ Prediction } & Pre & 40 & 1.9000 & 0.98189 & \multirow{2}{*}{9.442} & \multirow{2}{*}{0.01} \\
\hline & Post & 40 & 3.9000 & 0.98189 & & \\
\hline \multirow[t]{2}{*}{ Problem Solving } & Pre & 40 & 1.2500 & 0.74248 & \multirow{2}{*}{11.473} & \multirow{2}{*}{0.01} \\
\hline & Post & 40 & 3.0500 & 0.71432 & & \\
\hline \multirow{2}{*}{ Total skill } & Pre & 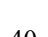 & 15.0500 & 2.95218 & \multirow{2}{*}{17.470} & \multirow{2}{*}{0.01} \\
\hline & Post & 40 & 26.5500 & 2.81889 & & \\
\hline
\end{tabular}

Results in Table (3) show that the $t$ - value is highly significant at 0.01 level, which indicates that participants' mean score of each Reading Comprehension sub-skill in the post-test increased $(5.1750$, $4.2250, \quad 5.3750, \quad 4.8250, \quad 3.9000$, 3.0500). These results could be attributed to the implementation of (TSS) which was effective in improving each Reading Comprehension sub-skill.

A closer look to the total score, table (3) reveals that the pupils' mean score in the overall pre- Reading Comprehension test in the experimental group was (15.0500) compared to the mean score in the post-Reading Comprehension test which was (26.5500). The improvement in the mean score of the experimental group in the post-test indicates that the participants' performance in the overall Reading Comprehension has been developed due to Text Structure Strategy (TSS).

\section{The Effect size of the proposed TSS}

First, eta square ( $\eta 2)$ was estimated to calculate the effect size of the proposed strategy on the pupils' Reading Comprehension skills . Eta square ( $\eta 2)$ was estimated after calculating the $t$-value. The following table illustrates the effect size of the proposed strategy on the experimental group pupils' Reading Comprehension skills. 
Table (4): The Effect Size of using TSS on the Experimental group's Reading Comprehension sub-skills' development

\begin{tabular}{|c|c|c|c|}
\hline $\begin{array}{c}\text { Sub-Skills of } \\
\text { RC }\end{array}$ & Df & $\begin{array}{c}\text { Eta square } \\
\left(\boldsymbol{\eta}^{\mathbf{2}}\right)\end{array}$ & Level of effect size \\
\hline Understanding & 32 & 0.60 & High \\
\hline Text Attack Skills & 32 & 0.50 & High \\
\hline Searching & 32 & 0.60 & High \\
\hline Inference & 32 & 0.60 & High \\
\hline Prediction & 32 & 0.70 & High \\
\hline Problem Solving & 32 & 0.78 & High \\
\hline Total skill & 32 & 0.89 & High \\
\hline
\end{tabular}

Results in table (4) illustrate the eta square for each Reading Comprehesion sub-skills and the total of these sub-skills. The effect size values are $(0.60,0.50,0.60,0.60$, $0.70,0.78$ ). This indicate respectively a high effect size for all Reading Comprehesion sub-skills of the experimental treatment. The results of the t-test for paired samples indicate that there were statistically significant differences at level $<0.001$ between the mean scores of the experimental group on the pre - posttest administration and that the effect size was high. So, each sub-skill of the has been improved after adminstrating the program.

\section{3- Verifying the third hypothesis:}

The third hypothesis stated that " There is a statistically significant difference at 0.05 level between the mean score of the experimental group and the control group on the post administration of attitude scale in favor of the experimental group."

Paired T-test was used in order to compare the results, table (5) shows the results of pupils' attitude scale it the experimental and the control groups. 
Table (5): A comparison of the mean score of the experimental and control groups on the post administration of the Attitude scale

\begin{tabular}{|c|c|c|c|c|c|c|}
\hline \multirow{8}{*}{ Attitude } & \multirow{2}{*}{ Groups } & \multirow{2}{*}{$\mathbf{N}$} & \multirow{2}{*}{ Mean } & \multirow{2}{*}{$\begin{array}{c}\text { Std. } \\
\text { Deviation }\end{array}$} & \multicolumn{2}{|c|}{ Paired T-test } \\
\hline & & & & & $\mathbf{T}$ & Sig \\
\hline & Experimental & \multirow{3}{*}{40} & \multirow{2}{*}{24.2250} & \multirow{2}{*}{3.61257} & \multirow{2}{*}{6.241} & \multirow{3}{*}{0.01} \\
\hline & Pre & & & & & \\
\hline & Post & & 29.3500 & 3.73171 & 8.345 & \\
\hline & Control & \multirow{3}{*}{40} & \multirow{2}{*}{28.300} & \multirow{2}{*}{3.93016} & \multirow{2}{*}{1.170} & \multirow{3}{*}{0.00} \\
\hline & Pre & & & & & \\
\hline & Post & & 28.550 & 3.802 & 1.88 & \\
\hline
\end{tabular}

Results in table (5) illustrate that there were differences in the participants' percentage in the pre post attitude scale in favor of the experimental group post administration of the attitude scale as this group had the higher percentage (29.3500). This indicates that there is a significant difference between the two groups in the pre - post attitude scale at significant level
(0.05) which proves that TSS Text Structure Strategy had a great effect on improving pupils' attitude.

\section{4-Testing the fourth hypothesis:}

The fourth hypothesis stated that "There is a statistically significant difference in 0.05level mean score of the experimental group in the attitude scale in favor of the pre-post administration."

Table (6): A comparison of the mean score of the experimental group pupilson the pre-post administration of the Attitude scale

\begin{tabular}{|c|c|c|c|c|c|}
\hline \multirow{2}{*}{} & \multirow{2}{*}{ Groups } & Mean & \multirow{2}{*}{$\begin{array}{c}\text { Std. } \\
\text { Deviation }\end{array}$} & \multicolumn{2}{|c|}{ Paired T-test } \\
\cline { 5 - 6 } & & & T & Sig \\
\hline \multirow{2}{*}{ Attitude } & Pre & 24.2250 & 3.61257 & 6.241 & \multirow{2}{*}{0.01} \\
\cline { 5 - 5 } & Post & 29.3500 & 3.37171 & 8.345 & \\
\hline
\end{tabular}

Table (6) clarifies that the tvalue in the total score is significant at 0.05 level. Thus, there is a statistically significant difference between the experimental group pupils' mean score in the pre- and postadministration of the attitude scale in favor of the post administration.
The results of the Experimental group pupils' percentages in Attitude scale (Table7) were significant in favor of the post-administration in most of the scale items. Consequently, the fourth hypothesis can be accepted. 
Table (7): A comparison of the experimental and control groups' percentages on the post Attitude scale (feeling about Reading Comprehension)

\begin{tabular}{|c|c|c|c|c|}
\hline & Attitude Items & $\begin{array}{c}\text { Number of } \\
\text { Jury } \\
\text { Agreement }\end{array}$ & Percentage $\%$ & Significance \\
\hline 1 & $\begin{array}{l}\text { I always feel happy when I read } \\
\text { things that are of interest to me. }\end{array}$ & 10 & $100 \%$ & Accepted \\
\hline 2 & $\begin{array}{l}\text { I enjoy sharing my knowledge } \\
\text { with my classmates during } \\
\text { reading. }\end{array}$ & 8 & $80 \%$ & Accepted \\
\hline 3 & $\begin{array}{l}\text { Reading is the best way to spend } \\
\text { free time }\end{array}$ & 8 & $80 \%$ & Accepted \\
\hline 4 & $\begin{array}{l}\text { I prefer reading stories and } \\
\text { magazines. }\end{array}$ & 10 & $100 \%$ & Accepted \\
\hline 5 & $\begin{array}{l}\text { I always make a mental perception } \\
\text { of what I read. }\end{array}$ & 9 & $90 \%$ & Accepted \\
\hline 6 & $\begin{array}{l}\text { I am looking for the highest } \\
\text { grades in reading. }\end{array}$ & 9 & $90 \%$ & Accepted \\
\hline 7 & $\begin{array}{l}\text { Reading adds a lot of information } \\
\text { to my experience }\end{array}$ & 10 & $100 \%$ & Accepted \\
\hline 8 & $\begin{array}{l}\text { Reading various texts in the } \\
\text { textbook interesting. }\end{array}$ & 8 & $80 \%$ & Accepted \\
\hline 9 & $\begin{array}{l}\text { I feel isolated as a pupil when I } \\
\text { take a reading passage. }\end{array}$ & 10 & $100 \%$ & Accepted \\
\hline 10 & $\begin{array}{l}\text { Pedagogical value of a course can } \\
\text { be enhanced through reading. }\end{array}$ & 9 & $90 \%$ & Accepted \\
\hline 11 & $\begin{array}{l}\text { I feel highly motivated to study } \\
\text { reading passages. }\end{array}$ & 9 & $90 \%$ & Accepted \\
\hline 12 & $\begin{array}{l}\text { I prefer reading about topics of } \\
\text { my interests. }\end{array}$ & 8 & $80 \%$ & Accepted \\
\hline 13 & $\begin{array}{l}\text { I practice reading when the } \\
\text { teacher asks me to do so. }\end{array}$ & 8 & $80 \%$ & Accepted \\
\hline 14 & $\begin{array}{l}\text { Reading solves many of the } \\
\text { educational problems. }\end{array}$ & 8 & $80 \%$ & Accepted \\
\hline 15 & $\begin{array}{l}\text { I believe that reading increases my } \\
\text { knowledge in various fields. }\end{array}$ & 9 & $90 \%$ & Accepted \\
\hline & Total & 9 & $90 \%$ & Accepted \\
\hline
\end{tabular}

Table (7) illustrates the fact that Pupils' attitude percentage increased due to the incorporation of (TSS )Text Structure Strategy. Comparing pupils' percentages in the experimental group shows that the pre-administration of considering the category "agree". This in turn, indicates that pupils in the post administration feel positive. The increase in pupils' attitude was mainly due to the implementation of Text Structure Strategy(TSS). 


\section{The Effect Size of Attitude scale}

The following table(8) illustrates the effect size of Attitude scale on the prepost administration of the experimental group.

Table (8):The Effect Size of Attitude scale on the pre- post administration of the experimental group

\begin{tabular}{|c|c|c|c|c|c|}
\hline & Groups & Mean & T value & $\begin{array}{c}\text { Eta square } \\
\left(\boldsymbol{\eta}^{2}\right)\end{array}$ & $\begin{array}{c}\text { Effect } \\
\text { size }\end{array}$ \\
\hline \multirow{3}{*}{ Attitude } & Pre & 24.2250 & 6.241 & 0.30 & Large \\
\cline { 2 - 6 } & Post & 29.3500 & 8.345 & 0.47 & Large \\
\hline
\end{tabular}

The results in table (8) indicate that $\mathrm{t}$-value of the experimental group (8.345) is higher than the t-value of the pre -administration (6.241). Moreover, Eta square of the post administration $(0.47)$ is higher than the Eta square of the pre test of the experimental group (0.30).

Based on the above analysis, it can be stated that Text Structure Strategy (TSS) is more effective in enhancing Reading Comprehension Skills of second year preparatory school pupils and their attitude towards reading.

\section{Interpretation of Results}

The results of this study ascertains the effects of TSS on Reading Comprehension Skills in order to identify the five expository text structures: description, sequence, cause/effect, compare/contrast, and problem/solution (Meyer, 1975, 1985). This study also indicates the large effect of the treatment on promoting the participants' reading comprehension skills. It builds directly on two previous intervention studies conducted with elementaryaged pupils experiencing reading difficulties (McLaughlin, 1990; Ocasio, 2006) and expository text structure research focused on the effects of expository text structure instruction on reading comprehension (Hebert et al., 2015).

Results revealed that there were three important findings especially linked to the proposed study in accordance to other studies. First, the obtained overall average weighted effect size of of using TSS on the Experimental group was( .87 ),indicates that TSS improves 2 nd preparartory pupils' Reading Comprehension Skills. However, there was a great deal of variability in the level effects for other studies conducted by McLaughlin (1990) and Ocasio(2006) ,with elementary-aged students were 0.11 and 2.8 , respectively.

Second, there is an evidence that participants benefit more from the comprehensiveness of text structure structure including the signal words for each structure. Researchers of other studies reviewed in the metaanalysis revealed that the most commonly taught text structure was compare/contrast, followed by simple 
description, cause/effect, problem solution, and sequence .

Third, Like a majority of studies, the researcher used only proximal measures of reading comprehension (i.e., researchercreated measures linked directly with the instructional focus of the intervention); whereas, researchers of other studies used only distal measures of reading comprehension (i.e., norm-referenced measures not aligned directly with the intervention effects).Researchers of the two previous studies used both proximal and distal measures of Reading Comprehension Skills as (Wijekumar, Meyer \& Lei, 2012; Wijekumar et al., 2014). The average effect sizes suggest that the treatment effects are less weighted when distal measures of reading comprehension are used to assess the effects of Text Structure Strategy.

Recent analysis of studies were conducted on Text Structure Strategy with students at the high-, middle-, and elementary-school levels (Hebert et al., 2015) . These studies met the following aspects :

1. The researchers provided empirical evidence equal to the research.

2. The design was an experimental, quasi-experimental, or counterbalanced

3. The study was employed with high school-age participants from (1: 12) grades.
4. Participants in the treatment group received expository text structures instruction in one or more of five structures identified by Meyer (1985): description, sequence, compare/contrast, cause/effect, and problem/solution.

5. Participants were positive, active ,and motivational during implementing the program and they express their attitude on every structure in reading comprehension passages through the interactive activities and exercises. On the other hand, the researcher noticed that the participants in the control group were not concerned about reading comprehension lessons and they only interested in the score of exam.

6. Expository texts were included in measuring results on Reading Comprehension Skills .

According to the previous discussion and statistical results, the mean scores of the experimental group were higher than the mean scores of the control group on the overall reading comprehension skills posttest. The mean scores of the experimental group on the postreading comprehension test in the overall reading comprehension skills were higher than their mean scores in the pretest, There was also an increase in the mean score of each sub-skill of the post reading comprehension skills test .The researcher could conclude that EFL second year preparatory 
stage pupils' reading comprehension skills have been improved. The proposed Text Structure Strategy (TSS) had a large effect on promoting pupils' reading comprehension skills. Finally, teaching TSS had a positive effect in enhacing pupils' reading comprehension skills and their attitude towards reading.

\section{Conclusion}

that $\begin{gathered}\text { current study concluded } \\ \text { enhancing }\end{gathered}$ comprehension skills and attitudes towards reading among second prep pupils is possible through the proposed Text Structure Strategy. It presented empirical evidence that poor readers can be motivated through Text Structure Strategy(TSS) learning.

\section{Pedagogical implications}

Based on the findings, the present study recommended the following:

Reading skills should receive more attention so as to be enhanced at pre college levels especially at the preparatory stage.

Teachers should be trained to use modern technology in teaching and testing.

Appropriate e-teaching tools ought to be selected carefully while teaching reading and to raise students' attitudes towards learning.

Integrating Text Structure Strategy reading comprehension instruction in the EFL curriculum whether implicit or explicit is recommended because it will help pupils' lifelong learning.
Pupils ought to adopt modern technology in teaching and learning in order to improve their levels in all academic fields.

\section{Suggestions for Further Research}

The current study suggested the following researches:

1. Applying the proposed Text Structure Strategy to different stages (i.e., primary, secondary and college) and to large samples.

2. Investigating the factors that affect students' reading on the web such as; language proficiency, background knowledge, motivation, age and gender

3. Analyzing the relationship between the students' learning styles and their preference for learning on the web.

4. Adopting various web tools in enhancing reading to make sure which is suitable for different pupils.

\section{References}

Babaie, E.\& Fard, F. (2014). The Effect of Collocation Awareness and English Text Structure Awareness on the Performance of Iranian Preuniversity Students in Reading Comprehension Tests. International Journal of Literature and Humanities (IJELLH),1(2), April 2014.

Dorkchandra, D. (2012). Enhancing English Reading Comprehension through a Text Structure Reading Strategy 
CALL Program. Ph.D., the Suranaree University of Technology.

Hall, K., Sabey, B., \& McClellan, M. (2005). Expository text comprehension: Helping primary-grade teachers use expository texts to full advantage. Reading Psychology: An International Quarterly, 26(3), 211-234.

Hebert, M., Bohaty, J., Nelson, J. R., \& Brown, J. A. (2015). A metaanalysis of the effects of text structure instruction on reading comprehension. Manuscript submitted for publication.

Manning, C. (2003). Improving Reading Comprehension through Visual Tools. MA, Eastern Nazarene College.

McLaughlin, E. M. (1990). Effects of graphic organizers and levels of text difficulty on less-proficient fifth-grade readers' comprehension of expository text (Doctoral dissertation). Retrieved from ProQuest Digital Dissertations (UMI No. 9030955).

Mehrpour, S, Sadighi, F\& Baghari, Z. (2012). "Teaching Reading Comprehension Strategies to Iranian EFL Pre-University Student". The Journal of Teaching Language Skills (JTLS). ( Spring 2012), 4 (1). Pp. 107-134.

Meyer, B. J. F. (1975). The organization of prose and its effects on memory. Amsterdam,
Netherlands: North-Holland Publishing.

Meyer, B. J. F. (1985). Prose analysis: Purposes, procedures, and problems. In B. K. Britton \& J. Black (Eds.), Understanding expository text: A theoretical and practical handbook for analyzing explanatory text (pp. 269-304). Hillsdale, NJ: Erlbaum.

Meyer, B.J.F., Ray.M. (2011). Structure strategy interventions: Increasing reading comprehension of expository text. International Electronic Journal of Elementary Education, 2011, 4(1), 127-152.

Newman, L. M. (2007). The effects of explicit instruction of expository text structure incorporating graphic organizers on the comprehension of third-grade students. Unpublished doctoral dissertation. The university of Maryland.

Ocasio, T. L. (2006). A comparison of two instructional programs to develop strategies to improve reading comprehension (Doctoral dissertation). Retrieved from ProQuest Digital Dissertations (UMI No. 3209082).

Pearson, P. D. \& Hamm, D. N. (2005). The assessment of reading comprehension: $\mathrm{A}$ review of practices - the past, present, and future. In S. G. Paris, \& S. A. Stahl (Eds.), Children's reading 
comprehension and assessment. (pp. 131 -160). Mahwah, NJ: Lawrence Erlbaum Associates Publishers.

Rabani, S., Akhondi, M., \& Azizmalayeri, F.(2015). Processing Information in Expository Passages Using Text Structure Strategies: International Journal of Educational Investigations, 2(2), 42-58. Available online at http://www.ijeionline.com.

Wijekumar, K. K., Meyer, B. J. F., \& Lei, P. (2012). Large-scale randomized control trial with 4th graders using intelligent tutoring of the structure strategy to improve nonfiction reading comprehension. Educational Technology Research and Development, 60, 986-1013.

Zhang, X. (2008). The effects of the formal schema in reading comprehension: An experiment with Chinese with Chinese EFL readers.

Computational Linguistics and Chinese Language Processing, 13(2), 197-214. 